Acta vet. scand. 1961, 2, 246-253.

Department of Physiology, Endocrinology and Bloodgrouping, The Royal Veterinary and Agricultural College, Copenhagen, Denmark.

\title{
THE M BLOOD GROUP SYSTEM OF THE PIG
}

By

\author{
P. Bräuner Nielsen
}

A series of investigations, the earliest from 1913 by Fishbein, have demonstrated that in the blood plasma of pigs normal agglutinins against erythrocytes of other pigs occurred. This phenomenon has been studied in detail by Szymanowski et al. (1926), Rang (1931) and later by Szent-Ivanyi and Szabo (1954).

However it is only first by the use, primarily of isoimmunizations and secondarily of hetero-immunizations in the study of blood groups, that it has become possible to obtain more complete knowledge of the antigen structure of the erythrocytes of pigs. English investigations, Goodwin et al. (1955, 1956, 1957), Joysey et al. (1959) and Danish investigations Neimann-Sфrensen et al. (1956), Andresen et al. (1957, 1959 A, 1959 B, 1959 C) have demonstrated a very large number of antigen factors, blood group factors, in this animal species.

By genetic investigations it was found further, that the blood group factors (Table 1) demonstrated by iso-immunizations were inherited as simple dominant characters and that they furthermore could be divided into 8 blood group systems. Studies on the blood groups in pig have here proved their practical value as a control to be used in breeding, Andresen et al. (1959).

\section{OWN INVESTIGATIONS}

In earlier Danish iso-immunizations in pigs, only one breed, the Danish Land-race was used. Experience with blood group factors in cattle in this institute led to the expectation that it would be possible to simplify the demonstration of new antigen factors by using one breed as donor and another breed as recipient, because it may be assumed that the difference in the antigen 
Table 1.

Pig blood group systems, factors and gene designations (Andresen, Jeppesen, Moustgaard 1959).

\begin{tabular}{|c|c|c|}
\hline $\begin{array}{l}\text { Blood group } \\
\text { system }\end{array}$ & $\begin{array}{l}\text { Blood group } \\
\text { factors }\end{array}$ & $\begin{array}{l}\text { Gene } \\
\text { designations }\end{array}$ \\
\hline $\begin{array}{l}\mathbf{E} \\
\mathbf{F} \\
\mathbf{G} \\
\mathbf{H} \\
\mathrm{I} \\
\mathrm{J} \\
\mathrm{K} \\
\mathrm{L}\end{array}$ & $\begin{array}{l}E_{a}, E_{b}, E_{e}, E_{f}, \\
F_{a}, \\
G_{a}, G_{b}, \\
H_{a}, H_{b}, \\
I_{a}, \\
J_{a}, \\
K_{a}, K_{b}, K_{d}, \\
L_{a},\end{array}$ & $\begin{array}{l}E^{b}, E^{e}, \text { Eae, Eef, Ebf, } \\
F^{a}, F^{-}, \\
G^{a}, G^{b}, \\
H^{a}, H^{b}, H^{-}, \\
I^{a}, I^{-}, \\
J^{a}, J^{-}, \\
K_{a}, K^{b}, K^{a d}, K^{-}, \\
L^{a}, L^{-},\end{array}$ \\
\hline
\end{tabular}

structure of erythrocytes would then be greater than when animals of the same breed are used. On the whole it is difficult within a population to demonstrate by immunization such antigenic factors as are found at a very high, or at a very low frequency.

Therefore iso-immunizations were made, using pigs of the Pietrain breed as donors and pigs of the Danish Land-race as recipients. Table 2 shows the known blood group factors of both recipient and donors. By using blood from donor 1 production of an anti- $K_{b}$ should be expected in the recipient. After weekly immunizations for a month, it was possible to demonstrate antibodies against donor blood cells in the blood serum of the recipient. The titer was approx. 1:8. Three months later the recipient was again immunized, but this time with erythrocytes of donor

Table 2 .

Blood types of donors and recipient.

\begin{tabular}{llllllllll}
\hline & \multicolumn{10}{c}{ System } \\
\cline { 2 - 9 } & A & E & F & G & H & I & J & K & L \\
\hline Recipient $\left(\mathbf{T}_{3}\right)$ & $-/-$ & b/e & a/ & a/b & a/- & a/ & a/ & a/ & $-/-$ \\
1st donor & $-/-$ & e/e & $-/-$ & a/a & a/- & a/ & a/ & b/- & $-/-$ \\
2nd donor & $-/-$ & e/ef & $-/-$ & $\mathbf{a} / \mathbf{b}$ & $\mathbf{a} /-$ & $\mathbf{a} /$ & $\mathbf{a} /$ & $\mathbf{a} /$ & $-/-$ \\
\hline
\end{tabular}

2 and "ghost" of donor 1. After this immunization (Table 2) anti- $\mathrm{K}_{\mathrm{b}}$ and anti- $\mathrm{E}_{\mathrm{f}}$ could be expected. As early as 14 days after the first re-immunization the blood serum of the recipient had 
a high content of antibodies (hemolytic and incomplete agglutinins) against the erythrocytes of the donor.

By investigating a large number of blood samples from pigs of the Danish Land-race chosen at random, it was found as expected, that serum of the recipient reacted with blood cells which were $A$ and - or $-K_{b}$ positive, but in some cases it also reacted with blood cells which neither possessed any of these antigens nor the $\mathrm{E}_{\mathrm{f}}$-antigen. Thus a non-expected antibody must have been produced. This was further demonstrated by cross-absorptions, Table 3. It appeared further from these investigations that

Table 3.

Reactivity of serum $T_{3}$ after different absorption.

\begin{tabular}{|c|c|c|c|c|c|c|c|c|c|c|c|c|c|}
\hline $\begin{array}{l}\text { Test } \\
\text { cells }\end{array}$ & $\begin{array}{l}\text { Reaction } \\
\text { before } \\
\text { absorptio }\end{array}$ & & & & Rea & $\begin{array}{l}\text { tions } \\
\text { with }\end{array}$ & $\begin{array}{l}\text { after } \\
\text { cells }\end{array}$ & $\begin{array}{l}\text { absor } \\
\text { from }\end{array}$ & ption & & & & $\begin{array}{l}\text { Relevant } \\
\text { known } \\
\text { antigenic } \\
\text { factors }\end{array}$ \\
\hline & & 6 & 7 & 10 & 11 & 12 & 13 & 14 & 15 & 16 & 17 & 24 & \\
\hline 6 & + & • & . & + & + & $\cdot$ & $\cdot$ & $\cdot$ & + & $\cdot$ & $\cdot$ & • & $\mathbf{K}_{\mathbf{b}}$ \\
\hline 7 & + & . & . & + & + & . & . & . & + & . & . & . & $\mathbf{K}_{\mathbf{b}}$ \\
\hline 10 & + & + & + & $\cdot$ & . & + & + & • & + & + & + & + & A \\
\hline 11 & + & + & + & + & . & + & + & + & + & + & + & + & A \\
\hline 12 & + & . & . & + & + & . & . & . & + & . & . & r & $\mathbf{K}_{\mathbf{b}}$ \\
\hline 13 & + & . & . & + & + & . & . & . & + & . & . & . & $\mathbf{K}_{\mathbf{b}}$ \\
\hline 14 & + & + & + & + & + & + & + & $\cdot$ & + & + & + & + & $\mathrm{A}, \mathrm{K}_{\mathrm{b}}$ \\
\hline 15 & + & + & + & + & . & + & + & + & . & + & + & . & \\
\hline 16 & + & . & . & + & + & $\cdot$ & $\cdot$ & . & + & . & . & . & $\mathbf{K}_{\mathbf{b}}$ \\
\hline 17 & + & . & . & + & + & . & . & . & + & . & . & . & $\mathbf{K}_{\mathbf{b}}$ \\
\hline 24 & + & + & + & + & + & + & + & + & + & + & + & . & $\mathbf{K}_{\mathbf{b}}$ \\
\hline
\end{tabular}

the new antibody, designated anti-DK ${ }_{6}$, which was produced by the immunizations, reacted both in hemolytic and in antiglobulin (Coombs) test, while the antibody $K_{b}$ only reacted in the Coombs test. Both the anti-A and the anti- $\mathrm{K}_{\mathrm{h}}$ bodies were removed by absorption with blood cells from animal No. 14 which, (Table 3), possessed both the A- $K_{b}$-antigens. Attempts at further fractionation by absorption with blood cells with which the serum reacted positive, were unsuccessful. The absorbed serum must therefore be considered a specific anti-serum which reacts with a specific antigen factor, designatéd, $\mathrm{DK}_{6}$.

The hereditary characters of this new blood group factor were studies by investigating the progeny from various parental combinations. Table 4 . 
Table 4.

The observed distribution of positive and negative progeny from different types of matings.

\begin{tabular}{lcrc}
\hline \multicolumn{1}{c}{ Typed mating } & $\begin{array}{c}\text { No. of } \\
\text { matings }\end{array}$ & $\begin{array}{c}\text { No of } \\
\text { positive }\end{array}$ & $\begin{array}{c}\text { No. of } \\
\text { negative }\end{array}$ \\
\hline $\mathrm{DK}_{6}$ positive $\times \mathrm{DK}_{6}$ positive & 2 & 8 & 0 \\
$\mathrm{DK}_{6}$ positive $\times \mathrm{DK}_{6}$ negative & 27 & 72 & 59 \\
$\mathrm{DK}_{6}$ negative $\times \mathrm{DK}_{6}$ negative & 80 & 0 & 342 \\
\hline $\mathrm{DK}_{6} /-$ positive $\times \mathrm{DK}_{6}$ negative & 24 & 60 & 59 \\
\hline
\end{tabular}

The parental combination $\mathrm{DK}_{6}$ negative $\times \mathrm{DK}_{6}$ negative gave no $\mathrm{DK}_{6}$ positive progeny. Further, $\mathrm{DK}_{6}$ heterozygote $\left(\mathrm{DK}_{6} /-\right) \times$ $\mathrm{DK}_{6}$ negative $\left(\mathrm{DK}_{6}-/-\right)$ parents gave the expected 1:1 segregation. Thus there can hardly be any doubt that the presence of the $\mathrm{DK}_{6}$ factor is controlled by a single gene dominant to its absence.

In order to determine whether the new factor genetically or serologically, belongs to some already known blood group systems, 202 animals, presumably unrelated, were "blood typed" using both the new serum and the test sera already in use at the department. The results of these investigations are to be seen in contingency tables $(2 \times 2$ tables $)$, Table 5. The $\chi^{2}$ values were computed, and in cases where one of the groups were less than 5, Fisher's exact method was applied (Race and Sanger 1958).

It appears from the table that no statistically significant relation was found between the $\mathrm{DK}_{6}$ factor and earlier known factors. This strongly indicates that the locus governing the $\mathrm{DK}_{6}$ factor represents a blood group system, hitherto unknown. This view is further supported by the results from experiments (Table 6) in test crossing the double heterozygous individual to double recessive. The table shows that, considering the limited numbers, there is a satisfactory agreement between the segregation found and that expected in concordance with the proposed independent inheritance of the new factor according to Mendels second law of segregation $1: 1: 1: 1$. The test crossing investigations did not include the $L$ and $J$ systems as the frequency of the $L$ factor is relatively low and that of the $J$ factor very high in the Danish Land-race. Even so it must be assumed - referring also to Table 5 - that the occurrence of the factor $\mathrm{DK}_{6}$ is due to a single 
Table 5 .

Investigation for possible association between $\mathrm{DK}_{6}$ and other known blood group factors.

\begin{tabular}{|c|c|c|c|c|c|}
\hline \multirow{2}{*}{$\begin{array}{l}\text { Blood } \\
\text { group } \\
\text { system }\end{array}$} & \multirow{2}{*}{$\begin{array}{l}\text { Blood } \\
\text { group } \\
\text { factor }\end{array}$} & \multirow{2}{*}{$\begin{array}{l}\text { Reac- } \\
\text { tivity }\end{array}$} & \multicolumn{2}{|c|}{ Reactivity with $\mathrm{DK}_{6}$} & \\
\hline & & & + & - & \\
\hline $\mathbf{A}$ & $\mathbf{A}$ & + & $\begin{array}{r}3 \\
19\end{array}$ & $\begin{array}{r}47 \\
133\end{array}$ & $P=0.16$ \\
\hline \multirow{4}{*}{$\mathbf{E}$} & $\mathbf{E a}$ & + & $\begin{array}{r}4 \\
18\end{array}$ & $\begin{array}{r}21 \\
159\end{array}$ & $P=0.28$ \\
\hline & $E_{b}$ & + & $\begin{array}{l}10 \\
12\end{array}$ & $\begin{array}{r}100 \\
80\end{array}$ & $\chi^{2}=0.81$ \\
\hline & $\mathrm{Ee}_{\mathbf{e}}$ & + & $\begin{array}{r}20 \\
2\end{array}$ & $\begin{array}{r}154 \\
26\end{array}$ & $P=0.38$ \\
\hline & $\mathrm{E}_{\mathbf{f}}$ & + & $\begin{array}{l}12 \\
10\end{array}$ & $\begin{array}{r}124 \\
56\end{array}$ & $\chi^{2}=1.83$ \\
\hline \multirow{2}{*}{ G } & $\mathbf{G}_{\mathbf{a}}$ & + & $\begin{array}{r}6 \\
16\end{array}$ & $\begin{array}{r}40 \\
140\end{array}$ & $\chi^{2}=0.28$ \\
\hline & $\mathrm{Gb}_{\mathrm{b}}$ & + & $\begin{array}{r}22 \\
0\end{array}$ & $\begin{array}{r}175 \\
5\end{array}$ & $P=0.56$ \\
\hline $\mathbf{F}$ & $\mathrm{Fa}_{\mathrm{a}}$ & + & $\begin{array}{r}1 \\
21\end{array}$ & $\begin{array}{r}31 \\
149\end{array}$ & $P=0.10$ \\
\hline \multirow{2}{*}{$\mathbf{H}$} & $\mathrm{H}_{\mathrm{a}}$ & + & $\begin{array}{l}10 \\
12\end{array}$ & $\begin{array}{r}109 \\
71\end{array}$ & $\chi^{2}=1.85$ \\
\hline & $\mathrm{Hb}_{\mathrm{b}}$ & + & $\begin{array}{r}1 \\
21\end{array}$ & $\begin{array}{r}9 \\
171\end{array}$ & $\mathrm{P}=0.70$ \\
\hline I & $\mathbf{I a}_{\mathbf{a}}$ & + & $\begin{array}{r}17 \\
5\end{array}$ & $\begin{array}{r}138 \\
42\end{array}$ & $\mathrm{P}>0.60$ \\
\hline $\mathbf{J}$ & $\mathrm{J}_{\mathbf{a}}$ & + & $\begin{array}{r}18 \\
4\end{array}$ & $\begin{array}{r}169 \\
11\end{array}$ & $P>0.06$ \\
\hline \multirow{3}{*}{$\mathrm{K}$} & $\mathbf{K} \mathbf{a}$ & + & $\begin{array}{l}12 \\
10\end{array}$ & $\begin{array}{r}71 \\
109\end{array}$ & $\chi^{2}=1.85$ \\
\hline & $\mathbf{K}_{\mathbf{b}}$ & + & $\begin{array}{r}13 \\
9\end{array}$ & $\begin{array}{r}112 \\
68\end{array}$ & $\chi^{2}=0.08$ \\
\hline & $K_{d}$ & + & $\begin{array}{r}4 \\
18\end{array}$ & $\begin{array}{r}25 \\
155\end{array}$ & $\mathrm{P}>0.39$ \\
\hline $\mathrm{L}$ & $\mathrm{La}$ & + & $\begin{array}{r}3 \\
19\end{array}$ & $\begin{array}{r}36 \\
144\end{array}$ & $P=0.35$ \\
\hline
\end{tabular}




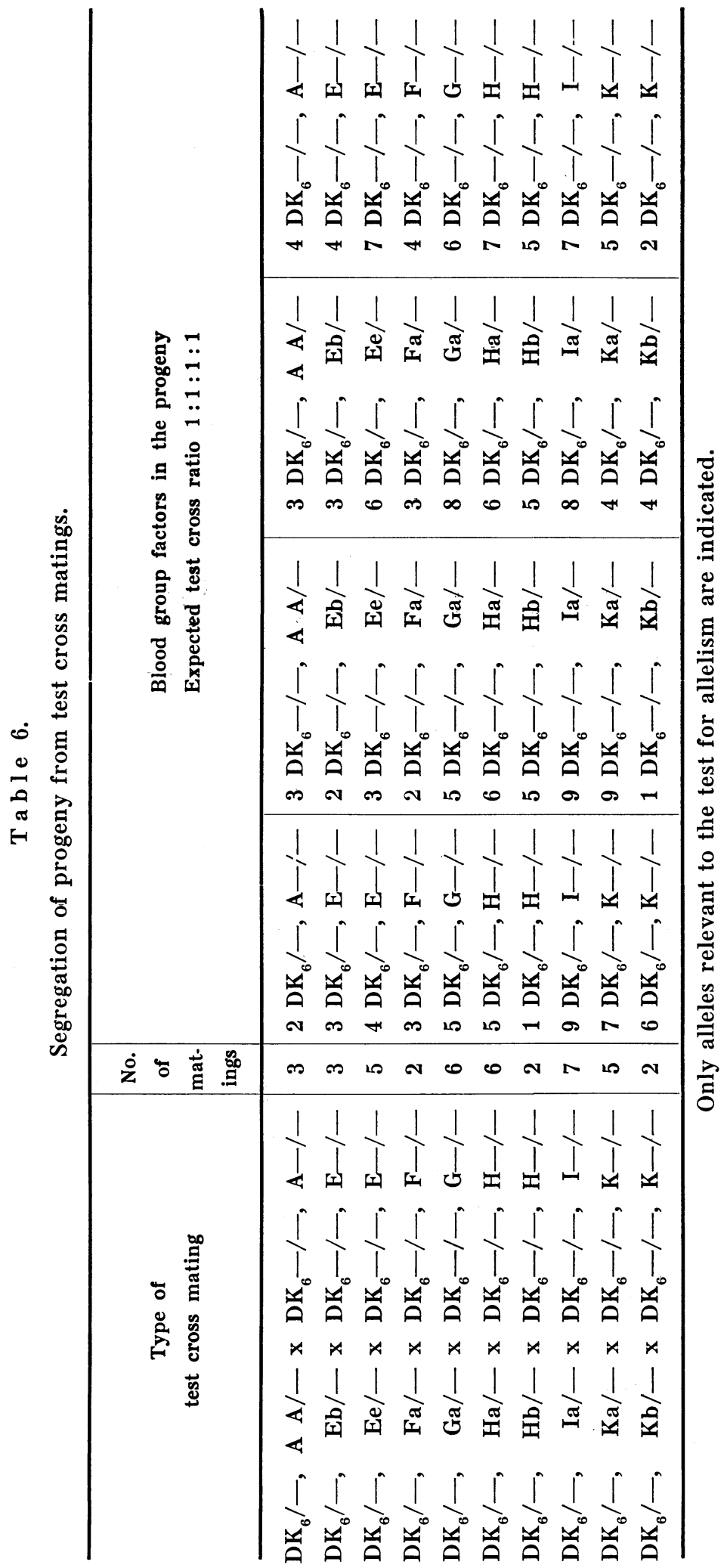


dominant inherited gene, independent of the known blood group genes so far found at this department. The new blood group system will, in agreement with earlier publications of the department on blood groups in pigs (Table 1) be designated the $M$ system, and the new factor, $M_{a}$. From the material investigated, the frequency of the $M^{a}$ gene in the Danish Land-race was computed and found to be $\mathbf{0 . 0 6}$.

\section{ACKNOWLEDGEMENT}

The author wish to thank Prof. J. Moustgaard, Head of this department and Dr. E. Andresen for helpful discussions and valuable suggestions.

\section{REFERENCES}

Andresen, E.: Nord. Vet.-Med. 1957, 9, 274.

Andresen, E. and Irwin, M. R.: Acta Agr. Scand., 1959 A, IX:3.

Andresen, E. and Irwin, M. R.: Nord. Vet.-Med., 1959 B, 11, 540.

Andresen, $E$. and Wroblewski, A.: Nord. Vet.-Med., 1959 C, 11, 548.

Andresen, E., Jeppesen, $R$ og Moustgaard, J.: Institut for Sterilitetsforskning, Årsberetning 1959, 242.

Fishbein, M.: J. inf. Dis. 1913, 12, 123.

Goodwin, R. F. W., Saison, R. and Coombs, R. R. A.: J. comp. Path. $1955,65,79$.

Goodwin, R. F. W. and Saison, R.: J. comp. Path. 1956, 66, 193.

Goodwin, R. F. W. and Saison, R.: J. comp. Path. 1957, 67, 126.

Joysey, V. G., Goodwin, R. F. W. and Coombs, R. R. A.: J. comp. Path. $1959,69,29$.

Joysey, V. C., Goodwin, R. F. W. and Coombs, R. R. A.: J. comp. Path. $1959,69,292$.

Neimann-Sфrensen, A., Sфrensen, P. H., Andresen, E. and Moustgaard, J.: VII Int. congres Animal Husbandry, Madrid 1956.

Rang, $F$.: Untersuchungen über die Isohaemagglutination im Blute des Schweines und Rindes mit eingeengten Seren. Diss. Göttingen 1931.

Szent-Iványi, Th., and Szabó, St.: Acta Vet. Acad. Scient. Hungar, 1954, 4, 429.

Szymanowski, Z., Stetkiewiez, St. and Wachler, B.: Compt. rend. Soc. Biol. 1926, 94, 204.

Szymanowski, Z. and Wachlezowna, B.: Compt. rend. Soc. Biol. 1926, 95, 923.

\section{SUMMARY}

The existence of a new blood group factor was demonstrated by immunizing a pig of the Danish Land-race with blood from pigs of the Pietrain race. Statistic and genetic investigations have proved or made probable that this new factor is inherited independently of 
blood group factors and blood group systems found to date in Danish investigations. The new factor should, according to the nomenclature used hitherto, be designated $M_{a}$ and the new blood group system, the M-system.

\section{ZUSAMMENFASSUNG}

Das M-System beim Schwein.

Bei der Iso-Immunisierung eines dänischen Landrassenschweines mit Blut von einem Schwein der Pietrainrasse wurde ein Antiserum gewonnen, mit dem sich ein neuer Blutgruppsfaktor nachweisen liess. Statistische und genetische Untersuchungen zeigten, dass der neue Faktor dominant und unabhängig von den bisher bei dänischen Untersuchungen gefundenen Bluttypen vererbt wird. In bezug auf die bislang angewandte Nomenklatur wird dieser neue Faktor mit $M_{a}$ und das neue Bluttypensystem mit M-System bezeichnet.

\section{RESUME}

M-systemet hos svin.

Ved iso-immunisering af et dansk landracesvin med blod fra svin af Pietrainracen fremstilledes et antiserum, med hvilket en ny blodtypefaktor påvistes. De statistiske og genetiske unders $\emptyset$ gelser viser, at den nye faktor nedarves dominant og uafhængig af de til dato ved danske unders $\varnothing$ gelser fundne blodtyper. I henhold til den hidtidigt anvendte nomenklatur vil den nye faktor blive betegnet $M_{a}$ og det nye blodtypesystem M-systemet.

(Received April 7. 1961). 